DOI: 10.46340/eujem.2020.6.6.11

Olga Bezpalko

ORCID ID: https://orcid.org/0000-0001-8589-4469

Vasyl' Stus Donetsk National University, Ukraine

HR-Deputy Director of JSC "Ukrzaliznytsia"

\title{
INCLUSIVE APPROACH TO THE FORMATION OF THE DEVELOPMENT STRATEGY FOR THE LOCAL COMMUNITY
}

\author{
Ольга Безпалько \\ Донецький національний університет імені Василя Стуса, Україна \\ Заступниця HR-директора AT "Укрзалізниця"

\section{ІНКЛЮЗИВНИЙ ПІДХІД ДО ФОРМУВАННЯ СТРАТЕГІЇ РОЗВИТКУ ТЕРИТОРІАЛЬНОЇ ГРОМАДИ}

The article reveals the factors that contribute to the development and effectiveness of the management of amalgamated local communities (hereinafter - OTG). The focus of the study differs significantly from most similar ones, mainly related to the analysis of the economic situation, material providing, legal basis for the functioning of local governments.

The new content of the principle of inclusiveness of OTG development strategy is substantiated. It involves creating a barrier-free environment and ensuring the availability of services, resources, infrastructure for all residents of the community in all areas of OTG. We indicate that "inclusiveness of OTG development strategy" is a higher-order idea that can guarantee the definition of the vector of modernization and provide a human-centered measurement of the effectiveness of achieving strategic priorities.

Key words: amalgamated local community, availability, inclusive strategy, efficiency, modernization of urban space.

\section{Постановка проблеми}

Розвиток об'єднаних територіальних громад в Україні потребує грунтовних досліджень, пов'язаних з пошуком та аналізом умов імплементації моделей ефективного управління місцевим розвитком, обгрунтуванням реалістичних шляхів самоідентифікації громад, підтримкою органів місцевого самоврядування на етапі становлення. Адже, об'єднані територіальні громади України опинились у суперечливій ситуації: з одного боку, вони мають забезпечити на професійному рівні впровадження досить розгалуженої системи базових послуг для громади, з іншого - центральними органами влади не створено реальних механізмів та організаційних інструментів втілення нової системи. Наразі триває перехідний період і все ще функціонують районні та обласні заклади, які виконують необхідні соціальні функції, а органам місцевого самоврядування таких громад, для надання соціальних послуг своїм жителям, дешевше перераховувати цим закладам субвенції. Такі тимчасові рішення, безумовно, допомагають заощаджувати бюджети громад. Проте з іншого боку, відбувається фактично його розпорошення через відсутність можливості у місцевої влади контролювати і впливати на процес надання доступних і якісних послуг своїм жителям та створювати якісну інфраструктуру й систему надання послуг ${ }^{1}$. Очевидно, що тривалий характер цього періоду негативно впливає на перспективу впровадження нової моделі розподілу відповідальності та забезпечення якості послуг для населення. Ключовий характер питання відповідальності в цьому контексті гальмує й інші процеси пошуку громадами автентичного шляху

\footnotetext{
${ }^{1}$ Портал «Децентралізація» (2016). Індикатори успішності та їх інструменти в системі управління місцевими громадами <https://decentralization.gov.ua/uploads/library/file/610/indykatory_cmprsd_.pdf> (2020, листопад, 12).
} 
розвитку, ідентифікації власного ресурсного потенціалу. Тобто йдеться про загострення проблеми управління ОТГ, уповільнення процесу налагодження сучасних механізмів взаємодії з органами влади. Критично важливими $є$ такі негативні наслідки: по-перше, тенденція до позбавлення перспективи досягнення базової мети реформи - впровадження моделі стратегічного розвитку, орієнтованого на жителів громади, по-друге, чергова хвиля демотивації та розчарування громад, остаточна втрата довіри у спроможність самостійно обрати та реалізувати європейську модель модернізації на місцевому рівні.

Найважливішим внутрішнім джерелом забезпечення ефективності діяльності територіальної громади $є$ обгрунтоване стратегічне бачення ії розвитку, яке має народитись в умовах спеціально організованої комунікації, метою якої є пошук та консолідація внутрішніх стейкхолдерів. Проте, в сучасних умовах, стратегії розвитку ОТГ переважно розробляються за допомогою консультацій експертів з різних фондів, в межах діяльності міжнародних програм технічної допомоги Україні. Ці процеси здійснюються, як правило, за визначеними алгоритмами та зосереджують стратегічні пріоритети навколо стандартних питань, які включать аспекти сталого розвитку, гендеру, залучення громади до прийняття рішень; окремим блоком $є$ акцент на індивідуальних особливостях громад. Разом $з$ цим, слід констатувати, що жоден підхід та жодна стратегія не забезпечують орієнтації на показники інклюзивності, які, на наш погляд, могли б претендувати на статус спеціальних індикаторів людиноцентрованості, які достатньо узагальнено, в широкому змістовному контексті спроможні відобразити комплекс параметрів доступності місцевого середовища та сучасних благ для всіх членів громади, що і є індикатором успішності реформи. Наполягаємо на широкому трактуванні показників інклюзивності та пропонуємо поєднати традиційне сприйняття з новими акцентами, які полягають у таких тезах: по-перше, сфера доступності не обмежується матеріальними складовими місцевого простору (фізична доступність), її важливими компонентами $є$ нематеріальні складові, які формують відчуття комфорту, безпеки, захищеності та впевненості в тому, що місцевий менеджмент зорієнтований на вирішення проблем кожного члена громади; по-друге, забезпечення доступності ідентифікується не лише фізичними змінами місцевого простору, критично важливою $\epsilon$ трансформація свідомості лідерів громади, яка має простежуватись у змісті та способах впровадження програмних документів, що визначають перспективи розвитку громади; по-третє, індикатори інклюзивності мають максимально охоплювати всі сфери життєдіяльності жителів громади, навіть емоційну сферу людини та проявлятись в архітектурній, транспортній, медичній, споживацькій, інституційній, ментальній, культурній та психологічній доступності широкого переліку послуг, релевантного потребам людини XXI століття. Усвідомлюючи амбітність зазначеної мети та відсутність умов для швидкого іiі досягнення, вбачаємо перспективу розвитку інструментарію стратегічного управління розвитком громад саме в послідовному впровадженні ідеї інклюзивності, як такої, що фокусує різноспрямовані дії та забезпечує реальну людиноцентрованість реформи.

\section{Аналіз останніх досліджень та публікацій}

Аналіз індикаторів ефективності об'єднаних територіальних громад якісно розглянуто в працях М. Євтушенко та Т. Лушагіної, в тому числі досліджено фактори ефективної комунікації з громадою, важливості залучення iï до розробки та реалізації стратегії розвитку ${ }^{1}$.

В достатній мірі розкрито ефективність управління місцевим розвитком у працях наступних вчених: О. Амосова, І. Гуськова, Є. Бабенкова, А. Кузнецова, О. Коротич, М. Латиніна та інших. Ресурсному забезпеченню територіальних громад особливу увагу приляють в своїх працях Ю. Дехтяренко, Г. Борщ, В. Вакуленко, Н. Гринчук, Л. Білуха та інші ${ }^{2}$. Інклюзивний розвиток сільської території в своїх працях розглядає Т. Зинчук, де інклюзія розглядається як основа політики максимального використання людського потенціалу на місцях ${ }^{3}$.

Разом $з$ тим, питання розробки та провадження інклюзивних стратегій розвитку, як складової управління в об'єднаних територіальних громадах України, ще не знайшли належного висвітлення у вітчизняних наукових працях.

\footnotetext{
${ }^{1}$ Євтушенко, О. Н., Лушагіна, Т. В. (2020). Об’єднані територіальні громади Миколаївської області в умовах децентралізації: індикатори ефективності. Public Administration and Regional Development, 8, 396-421. DOI: 10.34132/PARD2020.08.03.

${ }^{2}$ Білуха, Л. А. (2017). Поняття територіальної громади та спроможної територіальної громади. Теорія та практика державного управління, 1 (56), 1-6.

3 Зинчук, Т. (2019). Стратегія інклюзивного сільського розвитку на базі громад. Проекти, реалії та європейські перспективи для Украӥни. Київ: Центр навчальної літератури.
} 
Метою статті $є$ дослідження поняття “інклюзивна стратегія розвитку” територіальної громади, аналіз іiі складових та обгрунтування висновків щодо перспективи впливу зазначеного підходу на ефективність процесів розробки та реалізації моделі управління громадою.

\section{Виклад основного матеріалу дослідження}

Процеси впровадження моделей управління територіальними громадами в Україні характеризуються комплексом здобутків і проблем. Безумовно позитивний вплив мають тенденції поширення самосвідомості та самоідентифікації лідерів та жителів громад як ключових стейкхолдерів, які отримують реальні інструменти регулювання параметрів міського простору. Масовий характер концентрації зусиль громад на побудові власних стратегій розвитку допомагає критично оцінити наявний потенціал та знайти орієнтири розвитку. Разом 3 цим, спостерігається достатньо важлива проблема, яка часто набуває критичного значення - низький рівень обізнаності в питання місцевого розвитку та недостатній професіоналізм працівників органів місцевого самоврядування (далі - ОМС) в системі надання якісних послуг, що стає підставою формування розриву між очікуваннями, потребами жителів та рівнем їх задоволення. В свою чергу це породжує неефективність використання фінансового ресурсу громади, точніше розпорошеність бюджету та використання його на вирішення оперативних задач (так зване “гасіння пожеж”), що забирає ресурси з розробки та реалізації перспективних напрямів розвитку соціальної інфраструктури на рівні місцевих органів влади та в ОТГ.

Для заглиблення в аналіз окресленої проблеми варто застосувати два підходи компетентністний та ресурсний, які в сукупності визначають ефективність функціонування саме структури управління ОМС і ефективність використання потенціалу, яким орган місцевого самоврядування може користуватися. Компетентність органів місцевого самоврядування визначається рівнем якості наданих громадських послуг місцевому населенню (задоволеність роботою органів місцевого самоврядування. Ресурсний потенціал охоплює ресурси матеріальні, технічні, природні, інформаційні, будь-які інші, з можливістю їх перетворення на продукт (послуги для населення) та ступінь задоволення цими послугами від мешканців громади ${ }^{1}$.

Отже, кінцевим результатом оцінки має стати якість та доступність послуг, які надає орган місцевого самоврядування. Жителів громади цікавлять досягнуті результати діяльності органу місцевого самоврядування. В першу чергу - для усвідомлення правильності обраного курсу розвитку. Як правило, такий курс відображається в стратегії розвитку громади чи ії програмах. По-друге, таке усвідомлення та оцінка ефективності важлива, в тому числі, для визначення особистого рішення в період виборів голови ОТГ. Відповідно можна зробити висновок, що громадяни, які проживають в ОТГ оцінюють не стільки орган місцевого самоврядування, скільки результати його діяльності та ефективність управління².

В зазначеному контексті вибір способу здійснення якісного регулюючого впливу на розвиток громади потребує аналізу профілю реального жителя, його потреб та очікувань, життєвих планів та їхнього зв'язку з територіальною громадою, бажано в короткостроковій та довгостроковій перспективі. Відповіді на подібні питання мають стати підставою для визначення пріоритетів у найскладніший період - становлення ОТГ. Стратегічне планування розвитку ОТГ - це процес пошуку та обгрунтування напрямів розвитку громади; стратегія - це документ, зміст якого не може бути формальним, важливою $є$ орієнтація на реальні потреби територіальної громади, світобаченню громади щодо іiі місця в загальному розвитку регіону ${ }^{3}$. Ключовою в даному визначенні $\epsilon$ вимога "відповідати реальним потребам" - це означає враховувати особливості кожного жителя на всіх етапах - від стратегічного планування до оцінювання результатів реалізації стратегії. Отже, базовий стейкхолдер стратегічного планування розвитку громади - iї жителі, які мають різні демографічні характеристики, соціальний та економічний статус, цінності та здібності.

\footnotetext{
${ }^{1}$ Портал «Децентралізація» (2016). Індикатори успішності та їх інструменти в системі управління місцевими громадами <https://decentralization.gov.ua/uploads/library/file/610/indykatory_cmprsd_pdf> (2020, листопад, 12); Постанова про затвердження Методики формування спроможних територіальних громад, 2015 (Кабінет Міністрів України). Офіційний сайт Верховної Ради України <https://zakon.rada.gov.ua/laws/show/214-2015-\%D0\%BF> (2020, листопад, 12).

2 Портал «Децентралізація» (2016). Індикатори успішності та їх інструменти в системі управління місиевими громадами <https://decentralization.gov.ua/uploads/library/file/610/indykatory_cmprsd_.pdf> (2020, листопад, 12). ${ }^{3}$ Свтушенко, О. Н., Лушагіна, Т. В. (2020). Об'єднані територіальні громади Миколаївської області в умовах децентралізації: індикатори ефективності. Public Administration and Regional Development, 8, 396-421.
} DOI: 10.34132/PARD2020.08.03. 
Особливості громади є дзеркалом іiі потреб. При цьому вважаємо, що індикатором потреб жителів мають стати специфічні потреби особливих категорій, таких, що мають обмежені можливості доступу до різних благ, наприклад, маломобільні групи населення - батьки із дитячими візками, чи найбільша групу населення - пенсіонери. Очевидно, що в якийсь період життя ця категорія людей отримує особливу потребу в рівноцінній доступності всіх муніципальних приміщень, громадському транспорті та іншому, без застосування додаткових фізичних зусиль.

Очевидно, що доступність означає універсальні (інклюзивні) підходи до управління на рівні ОТГ. Це процес створення просторів, продуктів чи послуг максимально зручних, а значить і безпечних для всіх людей, незалежно від їхнього віку та фізичних чи когнітивних можливостей, без необхідності використання допоміжних (адаптивних) засобів або вузькоспрямованих спеціалізованих рішень ${ }^{1}$. Підкреслюємо, що досягнення високого рівня інклюзивності (доступності) місцевого простору як вирішена стратегічна задача має оцінюватись на основі аналізу ступеню задоволеності потреб саме специфічних категорій населення, людей, які не мають можливостей рівного доступу до суспільних благ певної громади.

Доступність протягом тривалого часу сприймалась як сукупність мінімальних технічних вимог до створення більш-менш сприятливих умов життєдіяльності обмеженої групи населення - людей з інвалідністю. Більше того, доступність здебільшого розглядалась лише як доступність архітектурного середовища для людей, які користуються інвалідними колясками. Проте в сучасному трактуванні «доступність» за змістом стає широким поняттям, що охоплює комплекс сфер: освіта, транспорт, працевлаштування, способи подання інформації, будівлі та громадські місця тощо. Багато з цих сфер перебувають у взаємній залежності. Наприклад, доступ до шкільного приміщення є однією з умов доступності освіти, що в кінцевому результаті впливає на залучення особистості в суспільне життя. Доступний транспорт дає можливість розширити межі мобільності та створити найбільш сприятливі умови для працевлаштування, навчання та відпочинку ${ }^{2}$. Всі ці сфери безпосередньо належать до повноважень органів місцевого самоврядування територіальних громад, де менеджмент та політика $\mathrm{OMC}$ повинна належним чином спряти якісному доступу всіх жителів громади до цих послуг.

Проте, спільнота вчених робить основний акцент на врахуванні під час розробки стратегічного плану - фінансово-економічних, соціальних та інфраструктурних показників. Із загальної ланки соціального блоку випадає поняття “доступності” послуг, як важливий елемент для широкої категорії населення.

На основі зазначеного контексту пропонуємо визначення інклюзивної стратегії розвитку як людиноорієнтованого підходу (концепції), що передбачає такий спосіб створення та організації середовища, продуктів і послуг, який гарантовано забезпечує можливість скористуватися ними максимальній аудиторії, в ідеалі - всі бажаючі отримати певну послугу мають можливість це зробити та отримати очікуваний результат. Універсальність даного підходу полягає в інклюзивному принципі, який враховує потреби кожного і кожної, де в центрі уваги знаходиться людина.

Відомі, але недостатньо поширені в українських громадах проєкти забезпечення доступності, зазвичай не потребують завеликих додаткових коштів, але ефект $є$ суттєвим. Він полягає в двох площинах: по-перше, реальна допомога певним категоріям жителів громади; по-друге, соціальнопсихологічна підтримка, шляхом формування відчуття турботи саме про них з боку влади, що в сукупності значно підвищує катастрофічно низький рівень довіри та поваги до місцевих лідерів. Прикладом такого підходу може бути плаский вхід до адміністративних будівель чи медичних закладів в громаді. Таке застосування архітектурної доступності дасть можливість задовольнити потребу значної частини населення і принесе користь всім жителям громади, починаючи від людей з інвалідністю, завершуючи пересуванням людей з дитячими колясками, або особам, які переносить важкі коробки, чи інші громіздкі речі в приміщення. Також вдалими прикладами $\epsilon$ способи розширення аудиторії комунікації органу місцевого самоврядування $з$ жителями громади через телебачення чи інформаційні повідомлення. Застосування інклюзивного підходу в цій сфері дасть можливість створити інформаційну доступність та посилити іiі, якщо у відеоповідомленнях використовуватимуться субтитри - інформаційний матеріал стає доступним для ширшого кола аудиторії. Це не тільки корисно для слабочуючих або глухих людей, але це також допомагає зрозуміти суть того, що відбувається на екрані тим, хто дивиться інформаційне повідослення в галасливих умовах.

\footnotetext{
${ }^{1}$ Універсальний дизайн (2020). Як застосовувати в школах універсальний дизайн, стандарти доступності й розумне пристосування <https://ud.org.ua/novini-ta-podiji/428-2020-06-23-16-27-03> (2020, листопад, 12).

2 Там само.
} 
Надважливим та яскравим показником інклюзивного принципу є використання спрощеної мови повідомлень, інструкцій, яка дійсно поєднує абстрактні соціальні та політичні з неврологічними та психологічними елементами читання. Це дуже важливий компонент в цій сфері. Йдеться про простоту наданої інформації на стендах оголошень, при інформуванні через веб-ресурси ОТГ (сайти), при підгтовці звітів чи інформаційних запитів, що продукує ОМС в контексті легкості сприйняття цієї інформації кінцевим споживачем - жителем громади, іiі практичного характеру і корисності. Більше того, люди з дислексією мають труднощі при сприйнятті певних шрифтів. Тому вибір правильного шрифту, чи інфографіки при реалізації інформаційної політики ОМС, як мінімум задовольняє особливу потребу окремої категорії громадян, і як максимум інформація легко сприймається i використовується всіма.

Отже, інклюзивний підхід як ідея для врахування його в стратегії розвитку, розширює межі усвідомлення того, хто ж є нашим жителем громади, і на кого повинен бути орієнтований кінцевий результат діяльності ОМС громади. І, відповідно, найбільшим викликом сьогодення є впровадження підходу інклюзивності як стратегічного в управлінні ОТГ, або ж розробка інклюзивної стратегії розвитку.

Висновки. Хоча інклюзивний підхід $є$ найбільш підходящим для людей похилого віку та людей з інвалідністю, він водночас задовольняє потреби інших жителів громади, створюючи ситуацію, якою задоволені всі без винятку.

Інклюзивний підхід є стратегією, яка спрямована на те, щоб проєктування і компоненти будьякого середовища, виробів, комунікацій, інформаційних технологій чи послуг були однаково доступні та зрозумілі всім і відповідали вимогам спільного використання, максимальною мірою у якомога незалежний та природний спосіб, бажано без необхідності в адаптації, чи застосуванні спеціалізованих рішень.

Виходячи із проведеного аналізу, можна зробити висновок, що, інклюзивна стратегія покликана забезпечити перехід до менеджменту, який орієнтований на користувача i грунтується на холістичному підході, спрямованому на задоволення потреб всіх людей з урахуванням можливих змін їх здібностей протягом життя.

Отже, така стратегія та врахування іï принципів виходить за межі класичного сприйняття доступності і стає інтегрованою моделлю формування соціальної політики в усіх аспектах суспільного життя.

\section{References:}

1. Zakon pro dobrovilne obyednannya terytorialnykh hromad, 2015 (Verkhovna Rada Ukrayiny) [Law on Voluntary Association of Territorial Communities, 2015 (Verkhovna Rada of Ukraine)]. Ofitsiynyy sayt Verkhovnoyi Rady [Official site of the Verkhovna Rada] <http://zakon4.rada.gov.ua/laws/show/157-19> (2020, November, 12). [in Ukrainian].

2. Yevtushenko, O. N., Lushahina, T. V. (2020). Obyednani terytorialni hromady Mykolaïvskoï oblasti v umovakh detsentralizatsiï: indykatory efektyvnosti [United territorial communities of Mykolayiv region in the conditions of decentralization: efficiency indicators]. Public Administration and Regional Development, 8, 396-421. DOI: 10.34132/PARD2020.08.03. [in Ukrainian].

3. Bilukha, L. A. (2017). Ponyattya terytorialnoyi hromady ta spromozhnoyi terytorialnoyi hromady [The concept of territorial community and able territorial community]. Teoriya ta praktyka derzhavnoho upravlinnya [Theory and practice of public administration], 1 (56), 1-6. [in Ukrainian].

4. Portal Detsentralizatsiya (2016) [Decentralization Portal (2016)]. Indykatory uspishnosti ta yikh instrumenty $v$ systemi upravlinnya mistsevymy hromadamy [Performance indicators and their tools in the local community management system] <https://decentralization.gov.ua/uploads/library/file/610/indykatory_cmprsd_.pdf> (2020, November, 12). [in Ukrainian].

5. Universalnyy dyzayn (2020) [Universal design (2020)]. Yak zastosovuvaty $v$ shkolakh universalnyy dyzayn, standarty dostupnosti y rozumne prystosuvannya [How to apply universal design, accessibility standards and smart adaptation in schools] <https://ud.org.ua/novini-ta-podiji/428-2020-06-23-16-27-03> (2020, November, 12). [in Ukrainian].

6. Zynchuk, T. (2019). Stratehiya inklyuzyvnoho silskoho rozvytku na bazi hromad. Proekty, realiyi ta yevropeyski perspektyvy dlya Ukrayiny [Community-based strategy for inclusive rural development. Projects, realities and European perspectives for Ukraine]. Kyiv: Tsentr navchalnoyi literatury. [in Ukrainian].

7. Postanova pro zatverdzhennya Metodyky formuvannya spromozhnykh terytorialnykh hromad, 2015 (Kabinet Ministriv Ukrayiny) [Resolution on approval of the Methodology for the formation of affluent territorial communities, 2015 (Cabinet of Ministers of Ukraine)]. Ofitsiynyy sayt Verkhovnoyi Rady Ukrayiny [Official site of the Verkhovna Rada of Ukraine] <https://zakon.rada.gov.ua/laws/show/214-2015-\%D0\%BF> (2020, November, 12). [in Ukrainian]. 